\title{
Stability Properties of Chromium in Cr(VI)-Contaminated Soil Stabilized by Calcium Polysulfide $\left(\mathrm{CaS}_{5}\right)$
}

\author{
Yuan Yuan $\mathrm{Li}^{*}$ and Ting Ting Zhang**(***)† \\ *Qingdao University of Technology, Qingdao, 266033, China \\ **Wisdri City Environment Protection Engineering Limited Company, Wuhan, 430205, China \\ ***Wuchang Shouyi University, School of Urban Construction, Wuhan 430064, China \\ †Corresponding author: Ting Ting Zhang; ttz_dshb@163.com; ztt_cersm@163.com
}

Nat. Env. \& Poll. Tech.

Website: www.neptjournal.com

Received: 06-02-2020

Revised: 22-02-2020

Accepted: 02-05-2020

\section{Key Words:}

$\mathrm{Cr}(\mathrm{VI})$-contaminated soil

Stability properties

Speciation

Leachability

Calcium Polysulfide

\begin{abstract}
Calcium polysulfide $\left(\mathrm{CaS}_{5}\right)$ is widely used in stabilizing $\mathrm{Cr}(\mathrm{VI})$-contaminated soils. The stability properties of $\mathrm{Cr}(\mathrm{VI})$ and $\mathrm{Cr}$ are the most important indexes for evaluating the effectiveness of stabilized soil. This study investigated the effect of $\mathrm{CaS}_{5}$ dosage and curing age on the stability properties of $\mathrm{Cr}(\mathrm{VI})$ and $\mathrm{Cr}$ in contaminated soils and the relationship between leachability and $\mathrm{Cr}$ speciation. Results show that increasing the $\mathrm{CaS}_{5}$ dosage and curing age could improve the stability properties of $\mathrm{Cr}$ in stabilized soil. The leachability and $\mathrm{Cr}(\mathrm{VI})$ content in the stabilized soil significantly decreased along with increasing $\mathrm{CaS}_{5}$ dosage and curing age. The changes in the leachability of the soil were attributed to the changes in the $\mathrm{Cr}$ speciation distribution and microstructure of the stabilized soil. The exchangeable fraction was mainly converted into an oxidizable fraction, and a dense structure (ettringite and elemental sulphur) was formed along with increasing $\mathrm{CaS}_{5}$ dosage and curing age. The exchangeable and reducible fractions depended on $\mathrm{Cr}$ leachability, and the $\mathrm{Cr}$ in the synthetic precipitation leaching procedures predominantly resulted from the exchangeable and reducible fractions.
\end{abstract}

\section{INTRODUCTION}

As a common contaminant of soils in China (Zhang et al. 2018), chromium [Cr(VI)] is a toxic and carcinogenic material that has been categorized by the US Environmental Protection Agency (US EPA) as a class A human carcinogen (Kazakis et al. 2018). The chemical reduction can rapidly and effectively remove $\mathrm{Cr}(\mathrm{VI})$ and has been widely used to stabilize $\mathrm{Cr}(\mathrm{VI})$-contaminated soils (Chrysochoou et al. 2010). Calcium polysulfide $\left(\mathrm{CaS}_{5}\right)$ is commonly used for the remediation of $\mathrm{Cr}(\mathrm{VI})$-contaminated soil due to its cost-effectiveness. Reducing $\mathrm{Cr}(\mathrm{VI})$ by using $\mathrm{CaS}_{5}$ can be formulated as (Zhang et al. 2018)

$2 \mathrm{CrO}_{4}{ }^{2-}+3 \mathrm{CaS}_{5}+10 \mathrm{H}^{+} \leftrightarrow 2 \mathrm{Cr}(\mathrm{OH})_{3}+15 \mathrm{~S}+2 \mathrm{Ca}^{2+}+2 \mathrm{H}_{2} \mathrm{O}$

Although many studies have examined $\mathrm{CaS}_{5}$-stabilized $\mathrm{Cr}(\mathrm{VI})$-contaminated soils, most of these works have focused on $\mathrm{Cr}$ (VI) leachability and content (Wazne et al. 2007, Chrysochoou et al. 2010, Zhang et al. 2018). However, leaching tests, including toxicity characteristic leaching procedure (TCLP), synthetic precipitation leaching procedures (SPLP), and semi-dynamic leaching tests, can only provide a single leaching result at a specific period, and the leachability of $\mathrm{Cr}$ in stabilized soil is not a good predictor of the effectiveness of stabilized reductants
(Seaman et al. 1999, Tinjum et al. 2008). Previous studies show that the toxicity and mobility of heavy metals in soil are not only related to their content but are also greatly determined by the distribution of their speciation (Petrucci et al. 2011). Therefore, the speciation distribution of $\mathrm{Cr}(\mathrm{VI})$ is crucial in ensuring the environmental security of stabilized soil. In addition, the leachability content of $\mathrm{Cr}$ in stabilized soil remains constant regardless of the environment and service time. Many factors can also affect the stabilization process of $\mathrm{Cr}(\mathrm{VI})$-contaminated soil, among which reductant dosage and curing age are the most important (Tinjum et al. 2008). However, very few studies have methodically investigated the effect of reductant dosage and curing age on the leachability and species distribution of $\mathrm{Cr}(\mathrm{VI})$ in contaminated soils stabilized by $\mathrm{CaS}_{5}$.

Accordingly, this study explores the effect of $\mathrm{CaS}_{5}$ dosage and curing age on the stability properties of $\mathrm{Cr}(\mathrm{VI})$ in $\mathrm{CaS}_{5-}$ stabilized soil. The relationship between the leachability and speciation distribution of the $\mathrm{Cr}(\mathrm{VI})$ in $\mathrm{CaS}_{5-}$ stabilized soil is also examined. The findings of this work provide novel insights that can aid in evaluating the environmental security of $\mathrm{CaS}_{5}$-stabilized soil and in remediating $\mathrm{Cr}(\mathrm{VI})$ contaminated soils by using $\mathrm{CaS}_{5}$. 


\section{MATERIALS AND METHODS}

\section{Cr(VI)-Contaminated Soil}

Given its representativeness and repeatability, $\mathrm{Cr}(\mathrm{VI})$ contaminated soil was simulated by Chinese clay and $\mathrm{K}_{2} \mathrm{Cr}_{2} \mathrm{O}_{7}$ in this study (Zhang et al. 2019). The $\mathrm{Cr}(\mathrm{VI})$ content of the soil was $1000 \mathrm{mg} / \mathrm{kg}$, which is representative of $\mathrm{Cr}$ (VI)-contaminated soils in China (Zhang et al. 2009, Wang et al. 2014). The contaminated soil was mixed evenly and braised for 180 days under standard curing conditions $\left(20^{\circ} \mathrm{C}, 95 \%\right.$ humidity) to allow $\mathrm{K}_{2} \mathrm{Cr}_{2} \mathrm{O}_{7}$ and the soil to react adequately and to obtain an ageing contaminated soil.

\section{Stabilization of $\mathrm{Cr}(\mathrm{VI})$-Contaminated Soil by $\mathrm{CaS}_{5}$}

The $\mathrm{CaS}_{5}$ used in the study was Cascade®, a $29 \% \mathrm{CaS}_{5}$ solution obtained from Lian Yun Gang Industrial Technology Co. Ltd. without further purification. The experimental design is given in Table 1. The $\mathrm{Cr}(\mathrm{VI})$-contaminated soil, $\mathrm{CaS}_{5}$ and distilled water were homogenized in a mixer. The mixture was withdrawn from sealed plastic bottles after incubating for $3,7,15,28$, and 56 days at room temperature $\left(20^{\circ} \mathrm{C}\right)$.

\section{Test Methods}

The $\mathrm{Cr}(\mathrm{VI})$ contents of the soil and filtrate were measured by following the US EPA methods 3060A and 7196A, respectively, whereas the leachability of $\mathrm{Cr}(\mathrm{VI})$ and $\mathrm{Cr}$ was measured by following the US EPA method 1312. The sequential extraction procedure followed the method recommended by Rauret et al. (1999). Agilent 7700 inductively coupled plasma mass spectrometry was used to determine the metal concentrations in the leachate.

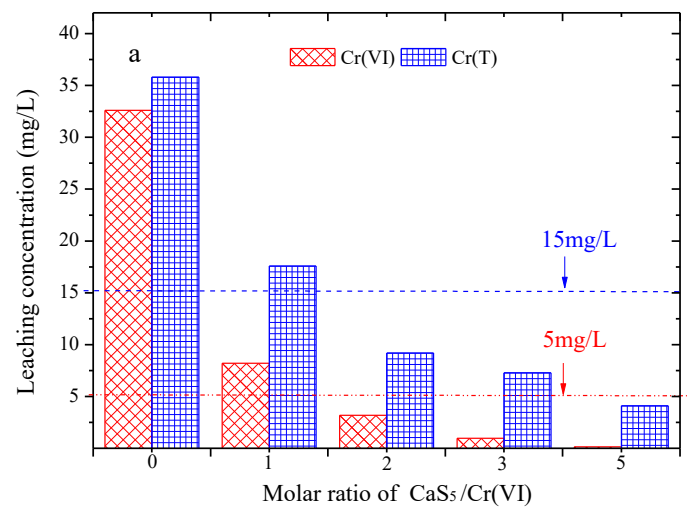

Table 1: Experimental design for the study.

\begin{tabular}{|lll|}
\hline Test No. & $\mathrm{CaS}_{5} / \mathrm{Cr}(\mathrm{VI})$ molar ration & Curing age \\
\hline 1 & 0 & $7 \mathrm{~d}$ \\
2 & 1 & $7 \mathrm{~d}$ \\
3 & 2 & $7 \mathrm{~d}$ \\
4 & 3 & $7 \mathrm{~d}$ \\
5 & 5 & $7 \mathrm{~d}$ \\
6 & 3 & $0 \mathrm{~d}$ \\
7 & 3 & $3 \mathrm{~d}$ \\
8 & 3 & $7 \mathrm{~d}$ \\
9 & 3 & $28 \mathrm{~d}$ \\
10 & 3 & $56 \mathrm{~d}$ \\
\hline
\end{tabular}

\section{RESULTS AND DISCUSSION}

\section{Leachability of $\mathrm{Cr}(\mathrm{VI})$ and $\mathrm{Cr}$ in Soil Before and After Stabilization}

In view of the leaching environment to be encountered when the stabilized soils are reused, an SPLP test was conducted to simulate the scenario of leaching associated with acid rain. Fig. 1 shows the leaching characteristics of the stabilized soil under different conditions. Fig. 1(a) reveals that both $\mathrm{Cr}(\mathrm{VI})$ and $\mathrm{Cr}$ concentrations decrease along with an increasing $\mathrm{CaS}_{5} / \mathrm{Cr}(\mathrm{VI})$ molar ratio. For untreated soil, the $\mathrm{Cr}(\mathrm{VI})$ and $\mathrm{Cr}$ leaching concentrations were approximately $32.6 \mathrm{mg} / \mathrm{L}$ and $35.8 \mathrm{mg} / \mathrm{L}$, respectively, which exceeded China's regulatory limits for hazardous wastes (China GB/ T5085.3-2007). For $\mathrm{CaS}_{5-}$ stabilized contaminated soil, when the $\mathrm{CaS}_{5} / \mathrm{Cr}(\mathrm{VI})$ molar ratio increased from 1 to 5 , the $\mathrm{Cr}(\mathrm{VI})$ and $\mathrm{Cr}$ leaching concentrations decreased from $8.2 \mathrm{mg} / \mathrm{L}$ and $17.6 \mathrm{mg} / \mathrm{L}$ to $0.14 \mathrm{mg} / \mathrm{L}$ and $4.08 \mathrm{mg} / \mathrm{L}$, respectively.

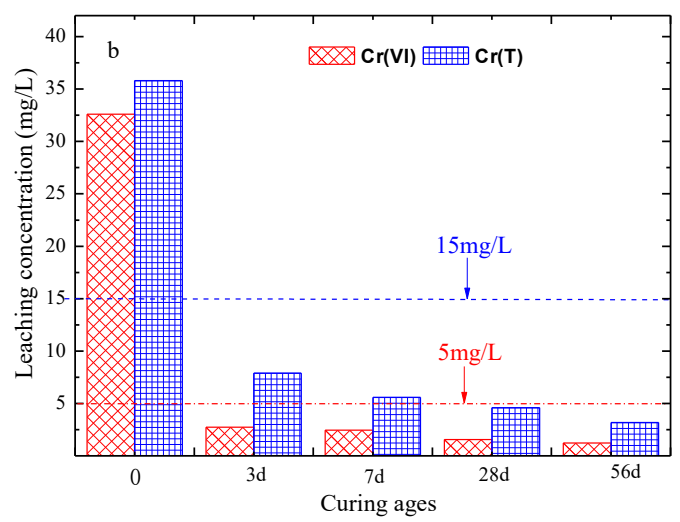

Fig. 1: $\mathrm{Cr}(\mathrm{VI})$ and $\mathrm{Cr}$ concentration of SPLP leachate under different conditions, (a) different $\mathrm{CaS}_{5}$ and $\mathrm{Cr}(\mathrm{VI})$ molar ratio, (b) different curing ages. 
In addition, when the $\mathrm{CaS}_{5} / \mathrm{Cr}(\mathrm{VI})$ molar ratio exceeded 2 , the $\mathrm{Cr}(\mathrm{VI})$ and $\mathrm{Cr}$ leaching concentrations complied with the regulatory limits of China and the US EPA (Moon 2008). The reduction in $\mathrm{Cr}(\mathrm{VI})$ concentration could be ascribed to the fact that $\mathrm{Cr}(\mathrm{VI})$ was reduced to $\mathrm{Cr}(\mathrm{III})$ and subsequently formed $\mathrm{Cr}(\mathrm{OH})_{3}$ and ettringite precipitation or $\mathrm{Cr}(\mathrm{III})$ was bound to sulphides and adsorbed sulphur surface, thereby hindering $\mathrm{Cr}$ from migrating through the soil (Chrysochoou et al. 2010).

The variations in the $\mathrm{Cr}(\mathrm{VI})$ and $\mathrm{Cr}$ concentrations of the stabilized soil under different curing ages are shown in Fig. 1 (b). The leaching concentrations of $\mathrm{Cr}(\mathrm{VI})$ and $\mathrm{Cr}$ in the leachate decreased along with an extended curing age. When the $\mathrm{CaS}_{5} / \mathrm{Cr}(\mathrm{VI})$ molar ratio was 3, the $\mathrm{Cr}(\mathrm{VI})$ and $\mathrm{Cr}$ concentrations complied with the regulatory limits of China and US EPA with a curing age of longer than $3 \mathrm{~d}$. The decrease in $\mathrm{Cr}(\mathrm{VI})$ and $\mathrm{Cr}$ concentrations may be attributed to the ageing process, more and more $\mathrm{Cr}(\mathrm{VI})$ solubilization, reduction and the following $\mathrm{Cr}(\mathrm{OH})_{3}$ and ettringite precipitation or adsorbed sulphur surface, making it harder for $\mathrm{Cr}$ to migrate through the soil, increasing the effectiveness of stabilized (Chrysochoou et al. 2010). As a result, the leaching concentrations of $\mathrm{Cr}(\mathrm{VI})$ and $\mathrm{Cr}$ decreased along with an extended curing age.

\section{$\mathrm{Cr}$ (VI) Content in Soil Before and After $\mathrm{CaS}_{5}$ Stabilization}

$\mathrm{Cr}(\mathrm{VI})$ content is often measured to guarantee the environmental security of stabilized soils being reused as construction materials. The China Environmental Regulation recommends minimum $\mathrm{Cr}(\mathrm{VI})$ contents of $30 \mathrm{mg} / \mathrm{kg}$ and 5 $\mathrm{mg} / \mathrm{kg}$ for industrial and civil reuse, respectively (China GB15618-2008). The Cr(VI) content in the soil before and after the stabilization of $\mathrm{CaS}_{5}$ is shown in Fig 2. As shown in Fig. 2(a), the $\mathrm{Cr}(\mathrm{VI})$ content in soil decreased along with an increasing $\mathrm{CaS}_{5} / \mathrm{Cr}(\mathrm{VI})$ molar ratio, thereby suggesting that the $\mathrm{CaS}_{5} / \mathrm{Cr}$ (VI) molar ratio significantly influences the effectiveness of the stabilized treatment. In addition, when the $\mathrm{CaS}_{5} / \mathrm{Cr}(\mathrm{VI})$ molar ratio was 5 , the $\mathrm{Cr}(\mathrm{VI})$ content of the contaminated soil was below the threshold specified by the China Environmental Regulation for industrial reuse $(<30$ $\mathrm{mg} / \mathrm{kg}$ ) (China GB15618-2008). Although the Cr(VI) and Cr leaching concentrations of the stabilized soil were negligible compared with those shown in Fig. 1, a considerable amount of $\mathrm{Cr}(\mathrm{VI})$ was still detected in the stabilized soil. Part residue $\mathrm{Cr}(\mathrm{VI})$ content of stabilized soil exceeded Environmental quality standards soil of China. The SPLP test underestimated the residue $\mathrm{Cr}(\mathrm{VI})$ content in the stabilized soil, and the leaching method could not reliably predict the remaining $\mathrm{Cr}(\mathrm{VI})$ content in the stabilized soil without performing an alkaline digestion test.

Fig. 2 (b) shows the variations in the $\mathrm{Cr}(\mathrm{VI})$ content in the soil as a function of curing age. As expected, the $\mathrm{Cr}(\mathrm{VI})$ content decreased along with an extended curing age, thereby suggesting that $\mathrm{CaS}_{5}$ has good stability and long residence time in the soil. In addition, when the curing age was $3 \mathrm{~d}$, the $\mathrm{Cr}(\mathrm{VI})$ content in the contaminated soil was below the threshold set by the China Environmental Regulation for industrial reuse $(<30 \mathrm{mg} / \mathrm{kg})$ yet satisfied the threshold for civil reuse $(<5 \mathrm{mg} / \mathrm{kg}$ ) when the curing age was extended to $56 \mathrm{~d}$ (China GB15618-2008) probably due to the fact that as the curing age increased from $3 \mathrm{~d}$ to $56 \mathrm{~d}$, most of the reactions between $\mathrm{Cr}(\mathrm{VI})$ and $\mathrm{CaS}_{5}$ were gradually completed, which could explain why the redox potential increased along with curing period.

\section{Species Distribution of $\mathrm{Cr}(\mathrm{VI})$ in Soil Before and After Stabilization}

The species distribution of $\mathrm{Cr}(\mathrm{VI})$ in the soil as a function of different $\mathrm{CaS}_{5} / \mathrm{Cr}(\mathrm{VI})$ molar ratios and curing ages is shown

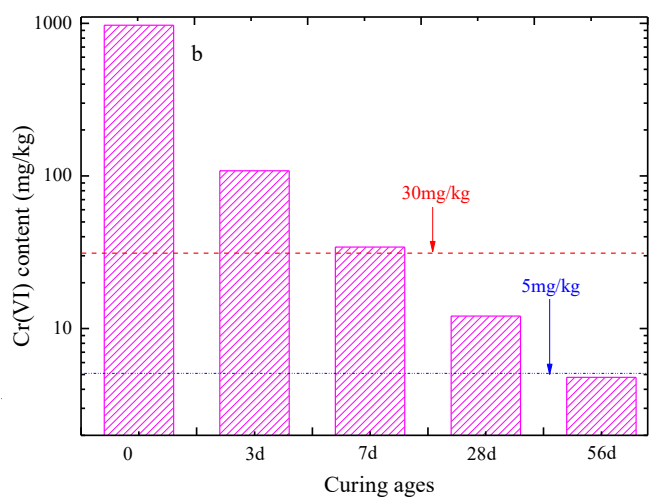

Fig. 2: $\mathrm{Cr}(\mathrm{VI})$ content in soil under different conditions, (a) different $\mathrm{CaS}_{5} / \mathrm{Cr}(\mathrm{VI})$ molar ratio, (b) different curing ages. 
in Fig. 3. Fig. 3(a) shows that for the untreated soil, Cr was mainly distributed in exchangeable $(0.79 \mathrm{mg} / \mathrm{g})$ and reducible fractions $(0.13 \mathrm{mg} / \mathrm{g})$, thereby indicating that $\mathrm{Cr}$ was highly mobile and toxic in the untreated contaminated soil. After $\mathrm{CaS}_{5}$ was stabilized, the species distribution of $\mathrm{Cr}(\mathrm{VI})$ in the soil was significantly changed. Specifically, as the $\mathrm{CaS}_{5} / \mathrm{Cr}(\mathrm{VI})$ molar ratio and curing ages increased, the oxidizable content of $\mathrm{Cr}$ in the stabilized soil significantly increased. As shown in Fig. 3(a), the exchangeable fraction was mainly converted into an oxidizable fraction. Meanwhile, as the $\mathrm{CaS}_{5} / \mathrm{Cr}(\mathrm{VI})$ molar ratio of the stabilized soil increased from 0 to 5, the oxidizable content of $\mathrm{Cr}$ increased from $0.076 \mathrm{mg} / \mathrm{g}$ to $0.88 \mathrm{mg} / \mathrm{g}$. In addition, a higher $\mathrm{CaS}_{5} / \mathrm{Cr}(\mathrm{VI})$ molar ratio benefitted the conversion of reducible fraction into an oxidizable fraction and decreased the reducible content of $\mathrm{Cr}$ from $0.15 \mathrm{mg} / \mathrm{g}$ to 0.021 $\mathrm{mg} / \mathrm{g}$. As shown in Fig. 3 (b), the oxidizable content of $\mathrm{Cr}$ increased from $0.076 \mathrm{mg} / \mathrm{g}$ to $0.68 \mathrm{mg} / \mathrm{g}$, thereby demonstrating that the $\mathrm{CaS}_{5}$ could significantly improve the chemical stability of $\mathrm{Cr}$. $\mathrm{CaS}_{5} / \mathrm{Cr}(\mathrm{VI})$ molar ratio and curing age were identified as crucial factors that control the species distribution of $\mathrm{Cr}$.

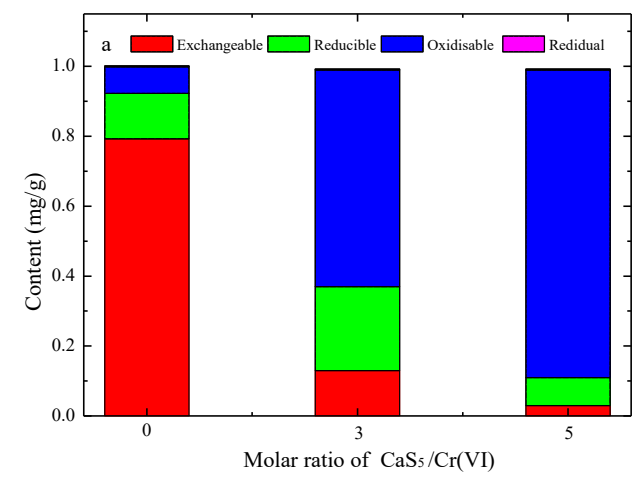

\section{Species Distribution of Cr(VI) in Soil Before and After SPLP Extraction}

The species distribution of $\mathrm{Cr}(\mathrm{VI})$ in the soil before and after SPLP extraction is shown in Fig. 4. After the SPLP extraction, the species distribution of $\mathrm{Cr}(\mathrm{VI})$ in the soil was significantly changed. The content of exchangeable and reducible fractions in all soils decreased, while the oxidizable and residual fractions were nearly unchanged. Fig. 4(a) shows that as the $\mathrm{CaS}_{5} / \mathrm{Cr}(\mathrm{VI})$ molar ratio of the stabilized soil increases from 0 to 5 , the exchangeable content decreases from $0.79,0.13$, and $0.03 \mathrm{mg} / \mathrm{g}$ to $0.18,0.06$, and $0.010 \mathrm{mg} / \mathrm{g}$, respectively, whereas the reducible content decreases from $0.13,0.24$, and $0.08 \mathrm{mg} / \mathrm{g}$ to $0.06,0.16$, and $0.02 \mathrm{mg} / \mathrm{g}$, respectively. Meanwhile, Fig. 4 (b) shows that the exchangeable content decreases from $0.79,0.13$, and $0.02 \mathrm{mg} / \mathrm{g}$ to $0.18,0.06$, and $0.008 \mathrm{mg} / \mathrm{g}$, respectively, whereas the reducible content decreases from $0.13,0.24$, and $0.14 \mathrm{mg} / \mathrm{g}$ to $0.06,0.16$, and $0.09 \mathrm{mg} / \mathrm{g}$, respectively, as the curing age extends from $0 \mathrm{~d}$ to $56 \mathrm{~d}$. These results clearly demonstrate that the exchangeable and reducible content of $\mathrm{Cr}$ depended on the $\mathrm{Cr}$ leachability in the SPLP test and on the safety of the stabilized soil.

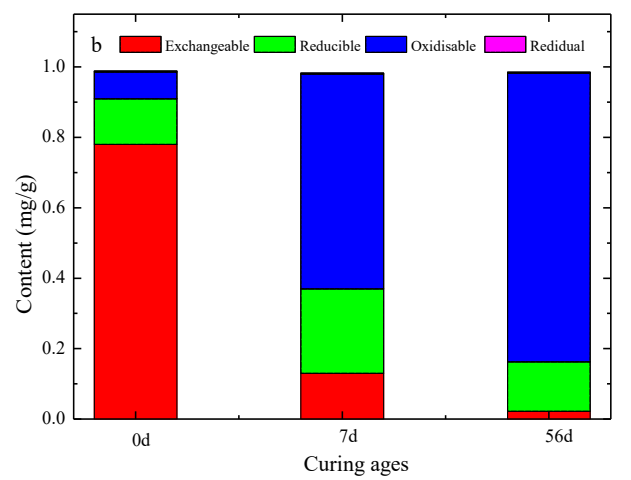

Fig. 3: Species distribution of $\mathrm{Cr}$ in soil under different conditions: (a) different $\mathrm{CaS}_{5} / \mathrm{Cr}(\mathrm{VI})$ molar ratio; (b) different curing ages.
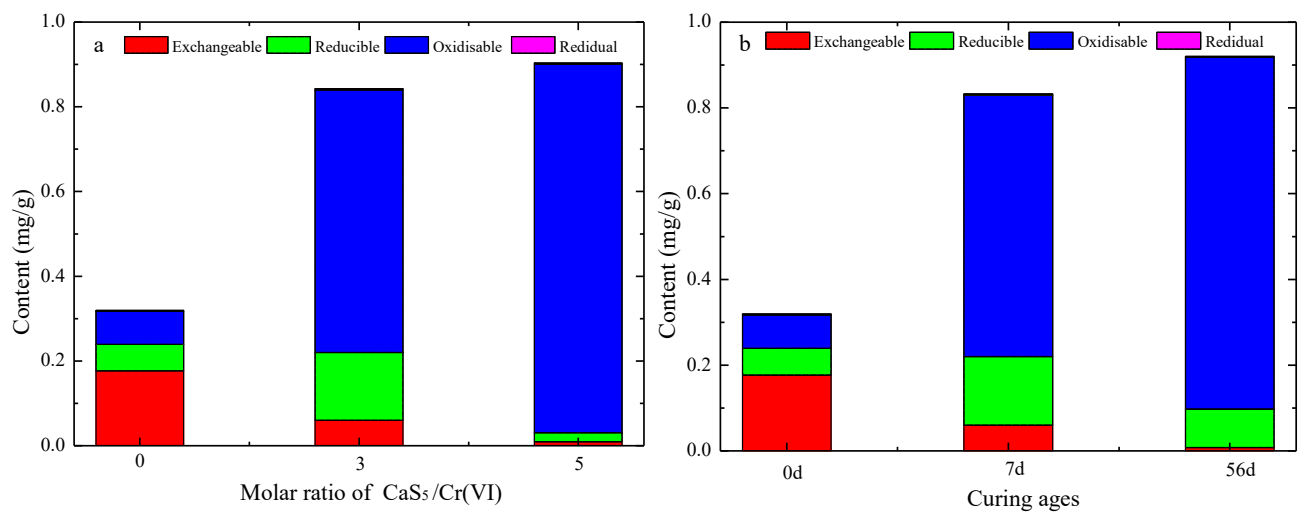

Fig. 4: Species distribution of $\mathrm{Cr}$ in soil after SPLP extraction (a) different $\mathrm{CaS}_{5} / \mathrm{Cr}(\mathrm{VI})$ molar ratio, (b) different curing ages. 


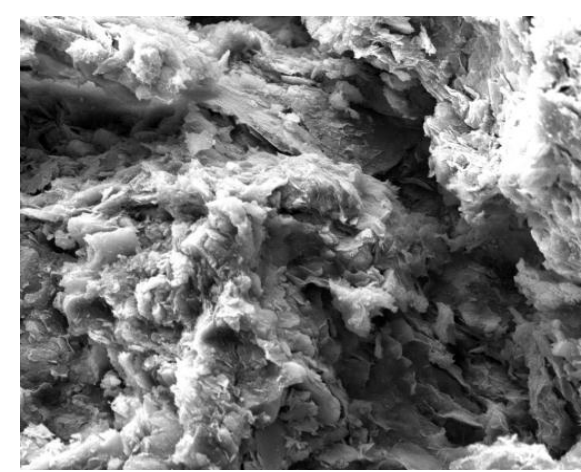

(a) untreated contaminated soil.

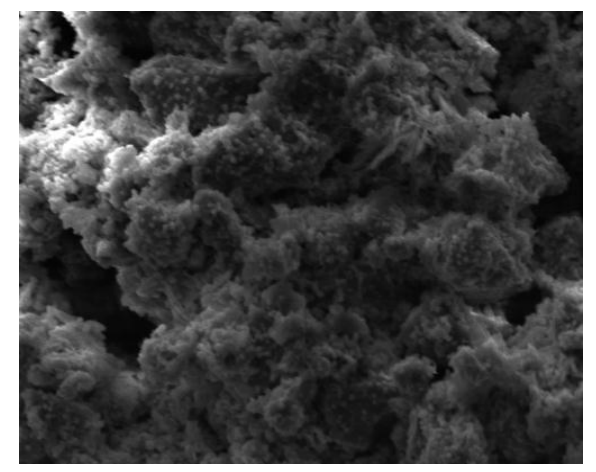

(c) $\mathrm{CaS} 5 / \mathrm{Cr}(\mathrm{VI})$ molar ratio was 3 and Curing age was $7 \mathrm{~d}$.

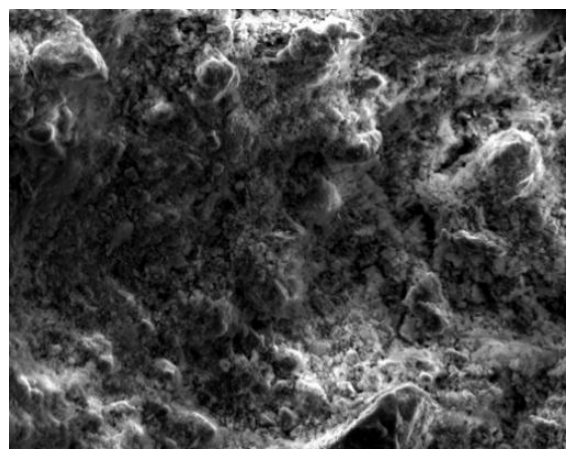

(b) $\mathrm{CaS} 5 / \mathrm{Cr}$ (VI) molar ratio was 5 and Curing age was $7 \mathrm{~d}$.

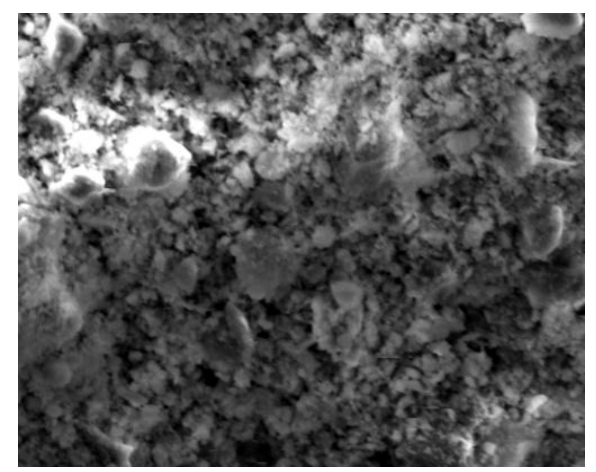

(d) $\mathrm{CaS} 5 / \mathrm{Cr}$ (VI) molar ratio was 3 and Curing age was $56 \mathrm{~d}$.

Fig. 5: SEM images of the stabilized soil under different conditions.

\section{SEM Analysis}

The typical SEM images of the stabilized soil under different conditions are shown in Fig. 5. The untreated contaminated soil (Fig. 5a) showed a large aggregate structure with a large void space between aggregations. When the $\mathrm{CaS}_{5} / \mathrm{Cr}(\mathrm{VI})$ molar ratio was 3 (Fig. 5 c), a low amount of ettringite and elemental sulphur was observed on the surface of the soil particles. By contrast, the SEM image of the soil with a $\mathrm{CaS}_{5} /$ $\mathrm{Cr}(\mathrm{VI})$ molar ratio of 5 showed a large amount of ettringite and elemental sulphur covering the surface of soil particles and forming a dense structure in the stabilized soil (Fig. $5 \mathrm{~b})$. When the curing age was extended from $7 \mathrm{~d}$ to $56 \mathrm{~d}$ (Fig. $5 \mathrm{c}$ and d), the void volume was decreased, and the soil particles showed a dense structure, thereby suggesting that increasing the $\mathrm{CaS}_{5}$ dosage and curing age would significantly change the microstructure of the soil and the stability properties of Cr. Zhou et al. (2017) and Chrysochoou et al. (2010) found that the $\mathrm{Cr}$ (III) uptake in ettringite hinders the release of $\mathrm{Cr}$ (III) from the soils during the leaching test.

\section{Relationship Between Species Distribution and Leachability of $\mathrm{Cr}$}

The relationship between $\mathrm{Cr}$ species distribution and leachability is given in Table 2 . The content of exchangeable and reducible fractions in all soils was decreased, whereas the oxidizable and residual fractions were nearly unchanged. In other words, the $\mathrm{Cr}$ in the SPLP leachate predominantly resulted from the exchangeable and reducible fractions, and the $\mathrm{Cr}$ content depended on the $\mathrm{Cr}$ leachability recorded in the SPLP test and on the environmental security characteristics of the stabilized soil. As for $\mathrm{CaS}_{5-}$ stabilized $\mathrm{Cr}(\mathrm{IV})$ contaminated soils, the leachability content of $\mathrm{Cr}$ remained constant regardless of the environment and service time.

Table 2 shows that the $\mathrm{Cr}$ content in the SPLP leachate is approximately equal to the decrements in the exchangeable and reducible fractions of the soil after the SPLP extraction. These results indicate that the content of exchangeable and reducible fractions can be used to evaluate the potential leachability of $\mathrm{Cr}$.

\section{CONCLUSIONS}

This study explores the speciation and leachability of $\mathrm{Cr}(\mathrm{IV})$-contaminated soils stabilized by $\mathrm{CaS}_{5}$. A series of SPLPs, alkaline digestions, sequential extractions, and SEM tests were performed on $\mathrm{Cr}(\mathrm{VI})$-contaminated soil. The effect of $\mathrm{CaS}_{5}$ dosage and curing age on $\mathrm{Cr}(\mathrm{VI})$ speciation and 
Table 2: Relationship between $\mathrm{Cr}$ species distribution and leachability of $\mathrm{Cr}$ in soil.

\begin{tabular}{|c|c|c|c|c|c|}
\hline \multirow[t]{2}{*}{ Soil types } & \multirow[t]{2}{*}{ Test indexes } & \multicolumn{4}{|c|}{ Species distribution of $\mathrm{Cr}(\mathrm{mg} / \mathrm{g})$} \\
\hline & & Exchangeable & Reducible & Oxidizable & Residual \\
\hline \multirow[t]{5}{*}{ Untreated soil } & Before SPLP extraction & 0.793 & 0.13 & 0.076 & 0.0026 \\
\hline & After SPLP extraction & 0.177 & 0.062 & 0.078 & 0.0023 \\
\hline & Variation & 0.616 & 0.068 & -0.002 & 0.0003 \\
\hline & Cr content in SPLP leachate & 0.716 & 0.716 & 0.716 & 0.716 \\
\hline & Percentage & $86.03 \%$ & $9.50 \%$ & $-0.27 \%$ & $0.042 \%$ \\
\hline \multirow{5}{*}{$\begin{array}{l}\mathrm{CaS} 5 / \mathrm{Cr}(\mathrm{VI}) \text { molar } \\
\text { ratio was } 3\end{array}$} & Before SPLP extraction & 0.13 & 0.24 & 0.62 & 0.00255 \\
\hline & After SPLP extraction & 0.06 & 0.16 & 0.62 & 0.00255 \\
\hline & Variation & 0.07 & 0.08 & 0 & 0 \\
\hline & $\mathrm{Cr}$ content in SPLP leachate & 0.146 & 0.146 & 0.146 & 0.146 \\
\hline & Percentage & $47.94 \%$ & $54.79 \%$ & 0 & 0 \\
\hline \multirow{5}{*}{$\begin{array}{l}\mathrm{CaS} 5 / \mathrm{Cr}(\mathrm{VI}) \text { molar } \\
\text { ratio was } 5\end{array}$} & Before SPLP extraction & 0.03 & 0.08 & 0.86 & 0.00253 \\
\hline & After SPLP extraction & 0.0098 & 0.021 & 0.87 & 0.00253 \\
\hline & Variation & 0.02 & 0.059 & -0.01 & 0 \\
\hline & Cr content in SPLP leachate & 0.082 & 0.082 & 0.082 & 0.082 \\
\hline & Percentage & $24.40 \%$ & $71.95 \%$ & $-12.2 \%$ & 0 \\
\hline \multirow[t]{5}{*}{ Curing age was $7 d$} & Before SPLP extraction & 0.13 & 0.24 & 0.62 & 0.00255 \\
\hline & After SPLP extraction & 0.06 & 0.16 & 0.62 & 0.00255 \\
\hline & Variation & 0.07 & 0.08 & 0 & 0 \\
\hline & Cr content in SPLP leachate & 0.146 & 0.146 & 0.146 & 0.146 \\
\hline & Percentage & $47.94 \%$ & $54.79 \%$ & 0 & 0 \\
\hline \multirow[t]{5}{*}{ Curing age was $56 \mathrm{~d}$} & Before SPLP extraction & 0.022 & 0.141 & 0.82 & 0.00256 \\
\hline & After SPLP extraction & 0.0078 & 0.09 & 0.81 & 0.00256 \\
\hline & Variation & 0.0142 & 0.051 & 0 & 0 \\
\hline & Cr content in SPLP leachate & 0.064 & 0.064 & 0.064 & 0.064 \\
\hline & Percentage & $22.19 \%$ & $79.69 \%$ & 0 & 0 \\
\hline
\end{tabular}

leachability were evaluated, and the relationship between $\mathrm{Cr}(\mathrm{VI})$ leachability and speciation was investigated. The following conclusions can be drawn from the results:

1. Increasing the $\mathrm{CaS}_{5}$ dosage and curing age can improve the stability of $\mathrm{Cr}$ in stabilized soil. The $\mathrm{Cr}(\mathrm{VI})$ leachability and content in stabilized soil significantly decreased along with increasing $\mathrm{CaS}_{5}$ dosage and curing age. The leachability and $\mathrm{Cr}$ content of the stabilized soil was lower than the regulatory limits imposed by China and the US EPA when the $\mathrm{CaS}_{5} / \mathrm{Cr}(\mathrm{VI})$ molar ratio was 3. Meanwhile, when the $\mathrm{CaS}_{5} / \mathrm{Cr}$ (VI) molar ratio was 5 , the $\mathrm{Cr}(\mathrm{VI})$ content in the soil met the environmental quality standards of China for industrial reuse (Cr(VI) $<30 \mathrm{mg} / \mathrm{kg}$ ).

2. The change in the leachability of soil was attributed to the changes in $\mathrm{Cr}$ speciation distribution. According to the results of the sequential extraction test, the exchangeable fraction was mainly converted into oxidizable fraction as the $\mathrm{CaS}_{5}$ was stabilized. The exchangeable and reducible fractions depended on $\mathrm{Cr}$ leachability, and the $\mathrm{Cr}$ in the SPLP leachate predominantly resulted from these fractions. The content of exchangeable and reducible fractions can be used to evaluate the potential leachability of $\mathrm{Cr}$.

3. Along with increasing $\mathrm{CaS}_{5}$ dosage and curing age, the microstructure of the stabilized soil was changed along with the stability properties of the soil. The SEM images showed that the stabilized soil had a large amount of ettringite, and elemental sulphur covered the surface of the soil particles and formed a dense structure in the stabilized soil.

\section{ACKNOWLEDGMENTS}

This study was supported by the thirteenth 3551 talent program of China optical valley (long-term innovative of Ting Ting Zhang), National Natural Science Foundation of Shandong 
province (ZR2020QE148), Natural Science Foundation of Qingdao University of Technology (2018TJZR002, 2019ZR007) and University research project of Shandong Province(J18KB059).

\section{REFERENCES}

Chrysochoou, M., Ferreira, D.R. and Johnston, C.P. 2010. Calcium polysulfide treatment of $\mathrm{Cr}$ (VI)-contaminated soil. Journal of Hazardous Materials, 179(1-3): 650-657.

Kazakis, N., Kantiranis, N. and Kalaitzidou, K. 2018. Environmentally available hexavalent chromium in soils and sediments impacted by dispersed fly ash in Sarigkiol basin (Northern Greece). Environmental Pollution, 235: 632-641.

Moon, D.H., Wazne, M. and Jagupilla, S.C. 2008. Particle size and pH effects on remediation of chromite ore processing residue using calcium polysulfide $\left(\mathrm{CaS}_{5}\right)$. Science of the Total Environment, 399(1-3): 2-10.

Petrucci, E., Montanaro, D. and Merli, C. 2011. Sequential extraction analysis provides decision-making tools for the use of contaminated sediments. Chemistry and Ecology, 27(S1): 107-118.

Rauret, G., Lopez-Sanchez, J.F. and Sahuquillo, A. 1999. Improvement of the BCR three step sequential extraction procedure prior to the certification of new sediment and soil reference materials. Journal of Environmental Monitoring, 1(1): 57-61.

Seaman, J.C., Bertsch, P.M. and Schwallie, L. 1999. In situ Cr (VI) reduction within coarse-textured, oxide-coated soil and aquifer systems using $\mathrm{Fe}$ (II) solutions. Environmental Science \& Technology, 33(6): 938-944.

Synthetic Precipitation Leaching Procedure, Method 1312. 1998. Environmental Protection Agency, Washington, D.C, U.S.

Tinjum, J.M., Benson, C.H. and Edil, T.B. 2008. Treatment of Cr (VI) in COPR using ferrous sulfate-sulfuric acid or cationic polysulfides. Journal of Geotechnical and Geoenvironmental Engineering, 134(12): 1791-1803.

Wazne, M., Jagupilla, S.C. and Moon, D.H. 2007. Assessment of calcium polysulfide for the remediation of hexavalent chromium in chromite ore processing residue (COPR). Journal of Hazardous Materials, 143(3): 620-628.

Zhou, X., Zhou, M. and Wu, X. 2017. Reductive solidification/stabilization of chromate in municipal solid waste incineration fly ash by ascorbic acid and blast furnace slag. Chemosphere, 182: 76-84.

Zhang, R., Zhang, N. and Fang, Z. 2018. In situ remediation of hexavalent chromium contaminated soil by CMC-stabilized nanoscale zero-valent iron composited with biochar. Water Science and Technology, 77(6): 1622-1631.

Zhang, T.T., Xue, Q. and Wei, M.L. 2018. Leachability and stability of hexavalent chromium contaminated soil stabilized by ferrous sulfate and calcium polysulfide. Applied Sciences, 8(9): 1431. 